\title{
THE USE OF $\mathrm{Ni}_{\mathrm{x}} \mathrm{Zn}_{\mathrm{x}} \mathrm{Fe}_{2} \mathrm{O}_{4}$ IN THE REMOVAL OF CONGO RED
}

\author{
Mahmoud Morsi ${ }^{(1)}$; Noha S. Donia ${ }^{(2)}$; Sherif Farag ${ }^{(3)}$ \\ and Ahmed F.Tawfic ${ }^{(4)}$
}

1) Post Graduate Student, Faculty of Graduate Studies and Environmental Research, Ain Shams University 2) Faculty of Graduate Studies and Environmental Research, Ain Shams University 3) Chemical analysis branch, Main Laboratories of Chemical warfare 4) Nuclear Engineering Department, Military Technical college, Kobry Elkoba

\begin{abstract}
Congo red is an organic dye used as a representative for organic contaminant of water; the prepared magnetic Nano particles is used in the removal of Congo red under many parameters including $\mathrm{pH}$ and the $\mathrm{Ni}_{\mathrm{x}} \mathrm{Z}_{\mathrm{nx}} \mathrm{Fe}_{2} \mathrm{O}_{4}$ concentrations. The results show that Congo red (CR) removal was succeeded using photo degradation method in the presence of $\mathrm{Ni}_{\mathrm{x}} \mathrm{Z}_{\mathrm{n} \times} \mathrm{Fe}_{2} \mathrm{O}_{4}$ as a catalyst. It succeeded to eliminate about $97 \%$ of $40 \mathrm{ppm}$ CR after 3 h. Photo catalytic degradation of CR could be carried out successfully over a $\mathrm{pH}$ range form 6-10. The $\mathrm{pH}$ affects not only surface properties of $\mathrm{Ni}_{\mathrm{x}} \mathrm{Z}_{\mathrm{nx}} \mathrm{Fe}_{2} \mathrm{O}_{4}$ nanoparticles but also the dissociation of dye molecule and the formation of the hydroxyl radical.
\end{abstract}

Keywords: $\mathrm{Ni}_{\mathrm{x}} \mathrm{Zn}_{\mathrm{x}} \mathrm{Fe}_{2} \mathrm{O}_{4}$, Congo red, Photo degradation, magnetic nanoparticles, Co-precipitation

\section{1-INTRODUCTION}

Water is the source of life on earth. It covers more than $75 \%$ of it and provides the suitable environment for the living organisms. Water forms 
Journal of Environmental Sciences (JES)

Faculty of Graduate Studies and Environmental Research, Ain Shams University

Morsi. et al.

nearly $80 \%$ of the cell mass [Brar et al; 2010]. Fresh water deficiency is a definition for water shortage or crisis as there is a shortage of access to fresh and potable water [Mahmoud et al; 2013]. This expression also refers to the pollution of the present water sources and to the difficulty in obtaining fresh water [Jumeria et al; 2014].

The main source for water pollution is from fertilizers and pesticides generated from industrial, farms and human wastes which dumped into rivers and lakes without prober treatments, other sources are oil spill on the ground and waste water leakage from landfills which may goes underground and pollute the underground water sources [Aoa et al; 2008].

Highly colored waste existence is of great importance as it prevent penetration of light thus affects the biological process within water stream. Beside that some dyes are carcinogenic and toxic [Sua et al; 2012]. It is estimated that $10-50 \%$ of the dye is lost in the effluent [Rahimi et al; 2011].

$\mathrm{Ni}_{\mathrm{x}} \mathrm{Zn}_{\mathrm{x}} \mathrm{Fe}_{2} \mathrm{O}_{4}$ is used in hardness natural organic compounds and alkalinity removal, decolorisation of pulp mill effluent and desalination [Chenga et al; 2015]. After adsorption, $\mathrm{Ni}_{\mathrm{x}} \mathrm{Zn}_{\mathrm{x}} \mathrm{Fe}_{2} \mathrm{O}_{4}$ can be removed from the medium by a magnet. It is a nontoxic, scalable economic and efficient method. Synthesis of $\mathrm{Ni}_{\mathrm{x}} \mathrm{Zn}_{\mathrm{x}} \mathrm{Fe}_{2} \mathrm{O}_{4}$ nanoparticles is highly preferred for potential application and fundamental research [Li et al; 2011].

Properties of Nano-ferrites such as (structural, magnetic, electrical, dielectric, optical etc.) are very sensitive to the preparation method and other 
synthesis parameters. Therefore, the selection of an appropriate synthesis method is the key to obtain high quality ferrites. [Aoa et al ;2008].

\section{2-EXPERIMENTAL WORK}

Basic data about chemicals, equipment and instruments are given. Also, procedures for evaluation of the photocatalytic potentials of $\mathrm{Zn}_{x} \mathrm{Ni}_{(1-\mathrm{x})} \mathrm{Fe}_{2} \mathrm{O}_{4}$ nanoparticles for selected contaminants are demonstrated. Additionally, the different possible parameters affecting photocatalytic efficiency are reported.

\subsection{Chemicals}

All the chemicals used in the experimental work were used directly without any additional purification or treatment. Table (1) summarize all the chemicals utilized in this work during different steps, indicating their specified purities, grade, and suppliers.

\subsection{Types of the used contaminants}

\subsection{1 congo red}

Congo red is an organic compound, the sodium salt of 3,3'-([1,1'biphenyl]-4,4'-diyl)bis(4-aminonaphthalene-1-sulfonic acid)(figure 1). It is an azo dye. Congo red is water-soluble, yielding a red colloidal solution; its solubility is greater in organic solvents [Di Paolaa A et al ; 2011 and Praveena1 et al; 2015].

\subsection{Nano ferrite preparation}

Iron (III) nitrate, $\mathrm{Fe}\left(\mathrm{NO}_{3}\right)_{3} \cdot 9 \mathrm{H}_{2} \mathrm{O}$, nickel(II) nitrate, $\mathrm{Ni}\left(\mathrm{NO}_{3}\right)_{2} \cdot 6 \mathrm{H}_{2} \mathrm{O}$, and zinc nitrate, $\mathrm{Zn}\left(\mathrm{NO}_{3}\right)_{2} \cdot 6 \mathrm{H}_{2} \mathrm{O}$ were purchased from Acros Organics and PVP 
Journal of Environmental Sciences (JES)

Faculty of Graduate Studies and Environmental Research, Ain Shams University

Morsi. et al.

$(\mathrm{MW}=10,000)$ was supplied by Sigma Aldrich. All the chemical re-agents were of research grade and used without further purification. $3 \mathrm{~g}$ of PVP was dissolved in $100 \mathrm{ml}$ of de-ionized water at $343 \mathrm{~K}$ before mixing $0.2 \mathrm{mmol}$ of iron (III) nitrate, $0.025 \mathrm{mmol}$ of nickel nitrate and $0.075 \mathrm{mmol}$ zinc nitrate and the solution stirred for 2 hours. No precipitation occurred in the solution. The brown solution was poured into a glass Petri dish and heated at $353 \mathrm{~K}$ in an oven for 24 hours to release most of the water. The brown solid material was crushed into powder and the samples were heated for 3 hours in alumina boat at different calcination temperatures of $723,773,823$ and $873 \mathrm{~K}$ to decompose the organic matters and crystallize the nanoparticles.[ Peternele $e t$ $a l ; 2014]$

\subsection{Photo catalytic reactor}

The removal of the contaminants by ultraviolet illumination which is called the photo catalytic process. Also, the photolysis of the contaminants was reported. In order to achieve a full evaluation of the synthetized Nano ferrite. The used UV reactor was a simple home made one. It consists of a glass measuring cylinder $(100 \mathrm{ml})$ having dimensions of $27 \mathrm{~cm}$ length, and 3 $\mathrm{cm}$ diameter. Figure (2) represents a full detailed description of the Photo catalytic Reactor setup.

To perform the photo catalytic decomposition experiments, the contaminants solutions and a certain amount of catalyst were loaded into the reactor.

Prior to the UV irradiation, aliquots of $1 \mathrm{ml}$ suspension were sampled using a syringe at specific time intervals for analysis. 
Journal of Environmental Sciences (JES)

Faculty of Graduate Studies and Environmental Research, Ain Shams University

Morsi, et al.

Vol.(50); Iss.(8); No.(5); Aug. 2021

ISSN 1110-0826

Online ISSN 2636-3178 
The photo decomposition efficiency (Removal \%) was calculated from the following equation:

Removal $\%=\left(1-\frac{C t}{C o}\right) \times 100$

Where $\mathrm{C}_{\mathrm{o}}$ is the initial concentration of the contaminant $(\mathrm{mg} / \mathrm{l})$, and $\mathrm{Ct}$ is the concentration at time $(\mathrm{t})$.

In the process of photo catalytic decomposition, the operating parameters, such as, catalyst type, catalyst concentration, initial concentration of contaminant, and $\mathrm{pH}$ were studied. Furthermore, optimum parameters were applied to different contaminates.

\subsection{Parameters affecting the photo catalytic process}

Different factors affect the photo catalytic process were studied. Optimizing chemical composition was the first one. It was a start point for further investigations according to different experimental conditions (photolysis/photo-catalysis). Moreover, the impact of thermal treatment of the photo catalyst on the photo catalytic process was examined. The optimum photo catalyst was examined under other parameters such as $\mathrm{pH}$, catalyst loading, and initial concentration. Furthermore, the photo catalytic activity against different organic contaminates was investigated.

To examine the influences of the $\mathrm{Ni}_{0.5} \mathrm{Zn}_{0.5} \mathrm{Fe}_{2} \mathrm{O}_{4}$ nanoparticles loading on the photo catalytic process of $\mathrm{CR}$, experiments were conducted using diverse concentrations of $\mathrm{Ni}_{0.5} \mathrm{Zn}_{0.5} \mathrm{Fe}_{2} \mathrm{O}_{4}$ varying from 200 to $500 \mathrm{mg} / 1$, 
Journal of Environmental Sciences (JES)

Faculty of Graduate Studies and Environmental Research, Ain Shams University

Morsi, et al.

using the same initial concentration of the CR under same experimental conditions.

Three values for $\mathrm{pH}$ were considered, covering the $\mathrm{pH}$ rage $(5,7$ and 9). The $\mathrm{pH}$ of the dye solution in the presence study is adjusted using $\mathrm{HNO}_{3}$ ( for lower $\mathrm{pH}$ ) and $\mathrm{NaOH}$ (for higher $\mathrm{pH}$ ).

\section{3-RESULTS AND DISCUSSION}

\subsection{PHOTOCATALYTIC POTENTIAL OF NixZn(1-x) $\mathrm{Fe}_{2} \mathrm{O}_{4}$ NANOPARTICLES}

$\mathrm{CR}$ is a typical and the first anionic synthetic dye, which has two azo ($\mathrm{N}=\mathrm{N}-$ ) chromophore [Di Paolaa et al; 2012]. Like other azo dyes, it is very stable because of its complex aromatic structure; it is not easily degradable. The stability of CR in water (hydrolysis) and under the exposure to UV radiation (photolysis) was examined. Figure (3) shows the degradation profile of $40 \mathrm{ppm} \mathrm{CR}$ in water with UV exposure for $3 \mathrm{~h}$. It was obvious that there is no significant degradation of CR in water, which was expected and confirmed regarding the employed CR concentration. Furthermore, photolysis of CR was also negligable since the produced $\mathrm{OH}^{\bullet}$ and $\mathrm{H}^{\bullet}$ radicals were not effective in UV-oxidation processes without suitable ferrite catalyst.

\subsection{EFFECT OF CATALYST CONCENTRATION}

Figure (4) shows the photo catalytic profiles for different concentrations of $\mathrm{Ni}_{0.5} \mathrm{Zn}_{0.5} \mathrm{Fe}_{2} \mathrm{O}_{4}$. It shows that the increase of photo degradation with relative increasing of concentration $\mathrm{Ni}_{0.5} \mathrm{Zn}_{0.5} \mathrm{Fe}_{2} \mathrm{O}_{4}$ for 40 ppm CR. Increasing

Vol.(50); Iss.(8); No.(5); Aug. 2021

331

ISSN 1110-0826

Online ISSN 2636-3178 
Journal of Environmental Sciences (JES)

Faculty of Graduate Studies and Environmental Research, Ain Shams University

Morsi. et al.

the concentration of $\mathrm{Ni}_{0.5} \mathrm{Zn}_{0.5} \mathrm{Fe}_{2} \mathrm{O}_{4}$ enhances photo degradation rate, which may be attributed to increasing the rate formation of hydroxyl radical due to the photo catalytic behaviour of $\mathrm{Ni}_{0.5} \mathrm{Zn}_{0.5} \mathrm{Fe}_{2} \mathrm{O}_{4}$. Which is mainly responsible for dye degradation of the existing contaminant. The overall photo degradation potentials for the $400 \mathrm{ppm}$ and $500 \mathrm{ppm}$ concentrations of the nano catalyst are very close. Therefore, it was convenient to select the 400 ppm concentration for further analysis.

\subsection{EFFECT OF pH}

In addition, exploring if $\mathrm{Ni}_{0.5} \mathrm{Zn}_{0.5} \mathrm{Fe}_{2} \mathrm{O}_{4}$ photocatalyst could be applied for a broad $\mathrm{pH}$ range.

Figure (5) represent the effect of $\mathrm{pH}$ on photo catalytic removal profiles of $40 \mathrm{ppm} \mathrm{CR}$ by $400 \mathrm{ppm} \quad \mathrm{Ni}_{0.5} \mathrm{Zn}_{0.5} \mathrm{Fe}_{2} \mathrm{O}_{4}$ nanoparticles at ambient temperature $25^{\circ} \mathrm{C}$. Obviously, the maximum removal of $\mathrm{CR}$ achieved at $\mathrm{pH} 6$, which could be attributed to relatively increase in $\mathrm{H}^{+}$ion concentration in the system with respect to higher $\mathrm{pH}$ values. Low $\mathrm{pH}$ leads to the surface of the $\mathrm{Ni}_{0.5} \mathrm{Zn}_{0.5} \mathrm{Fe}_{2} \mathrm{O}_{4}$ nanoparticles acquires a positive charge by absorbing $\mathrm{H}^{+}$ ions. Hereafter, the surface turn into positively charged at low $\mathrm{pH}$, a meaning

fully robust electrostatic attraction developed between the positively charged surfaces of $\mathrm{Ni}_{0.5} \mathrm{Zn}_{0.5} \mathrm{Fe}_{2} \mathrm{O}_{4}$ and $\mathrm{CR}$ molecule, leading to maximum adsorption of dye. As the $\mathrm{pH}$ of the system rises, the number of negatively charged spot rises and the number of positively charged spots declines. A negatively charged surface spot on the $\mathrm{Ni}_{0.5} \mathrm{Zn}_{0.5} \mathrm{Fe}_{2} \mathrm{O}_{4}$ nanoparticles does not prefer the adsorption an anionic dye molecule such as CR, due to the 332

Vol.(50); Iss.(8); No.(5); Aug. 2021

ISSN 1110-0826

Online ISSN 2636-3178 
electrostatic repulsion.On the other hand, the photo catalytic degradation of $\mathrm{CR}$ did not affect significantly with respect to $\mathrm{pH}$. Even, the relatively highest photo catalytic performance was also observed at $\mathrm{pH}$ 6. It is obviously that photo catalytic degradation of CR could be carried out successfully over a $\mathrm{pH}$ band form 6-10. The $\mathrm{pH}$ affects not only surface properties of $\mathrm{Ni}_{0.5} \mathrm{Zn}_{0.5} \mathrm{Fe}_{2} \mathrm{O}_{4}$ nanoparticles but also the dissociation of dye molecule and the formation of the hydroxyl radical. The decrease in CR degradation under alkaline condition attributed to the negative charge surface of ferrite because of the increase concentration of $\mathrm{OH}$ - radical, thereby repelling the dye molecule.

\section{4-CONCLUSION}

In summary, Photo degradation of Congo red in aqueous solutions with synthesized Ni/Zn ferrites was studied. The effects of amount of Nano Ni/Zn ferrites. The extreme photo catalytic effectiveness was achieved by $\mathrm{Ni}_{0.5} \mathrm{Zn}_{0.5} \mathrm{Fe}_{2} \mathrm{O}_{4}$, it succeeded to eliminate about $97 \%$ of $40 \mathrm{ppm}$ CR after $3 \mathrm{~h}$. Photo catalytic degradation of CR could be carried out successfully over a $\mathrm{pH}$ band form 6-10. The $\mathrm{pH}$ affects not only surface properties of $\mathrm{Ni}_{0.5} \mathrm{Zn}_{0.5} \mathrm{Fe}_{2} \mathrm{O}_{4}$

nanoparticles but also the dissociation of dye molecule and the formation of the hydroxyl radical. 
(1) List of chemicals

\begin{tabular}{|c|c|c|c|c||}
\hline \hline NO & CHEMICALS & $\begin{array}{c}\text { CHEMICAL } \\
\text { FORMULA }\end{array}$ & $\begin{array}{c}\text { PURITY / } \\
\text { GRADE }\end{array}$ & SUPPLIER \\
\hline \hline $\mathbf{1}$ & $\begin{array}{c}\text { Ferric sulfate } \\
\text { penta hydrate }\end{array}$ & $\mathrm{Fe}_{2}\left(\mathrm{SO}_{4}\right)_{3} \cdot 5 \mathrm{H}_{2} \mathrm{O}$ & $\begin{array}{c}98 \% \\
\text { RG }\end{array}$ & $\begin{array}{c}\text { MERCK } \\
\text { (Germany) }\end{array}$ \\
\hline $\mathbf{2}$ & Nickel sulfate & $\mathrm{Ni}_{2}\left(\mathrm{SO}_{4}\right)$ & $\begin{array}{c}99 \% \\
\text { RG }\end{array}$ & $\begin{array}{c}\text { MERCK } \\
\text { (Germany) }\end{array}$ \\
\hline $\mathbf{3}$ & $\begin{array}{c}\text { Zinc sulfate hepta } \\
\text { hydrate }\end{array}$ & $\mathrm{Zn}\left(\mathrm{SO}_{4}\right) \cdot 7 \mathrm{H}_{2} \mathrm{O}$ & $\begin{array}{c}99.5 \% \\
\text { RG }\end{array}$ & $\begin{array}{c}\text { MERCK } \\
\text { (Germany) }\end{array}$ \\
\hline $\mathbf{4}$ & $\begin{array}{c}\text { Sodium } \\
\text { Hydroxide pellets }\end{array}$ & $\mathrm{NaOH}$ & $\begin{array}{c}98 \% \\
\text { RG }\end{array}$ & $\begin{array}{c}\text { MERCK } \\
\text { (Germany) }\end{array}$ \\
\hline $\mathbf{5}$ & Acetone & $\mathrm{C}_{3} \mathrm{H}_{6} \mathrm{O}$ & $\begin{array}{c}99 \% \\
\text { RG }\end{array}$ & $\begin{array}{c}\text { MERCK } \\
\text { (Germany) }\end{array}$ \\
\hline $\mathbf{6}$ & Chlorpyrifos & $\mathrm{C}_{9} \mathrm{H}_{11} \mathrm{Cl}_{3} \mathrm{NO}_{3} \mathrm{PS}$ & $\begin{array}{c}95 \% \\
\text { Technically }\end{array}$ & $\begin{array}{c}\text { K.Z } \\
\text { (Egypt) }\end{array}$ \\
\hline $\mathbf{7}$ & Malathion & $\mathrm{C}_{10} \mathrm{H}_{29} \mathrm{O}_{6} \mathrm{PS}_{2}$ & $\begin{array}{c}95 \% \\
\text { Technically }\end{array}$ & $\begin{array}{c}\text { N.C.I.C } \\
\text { (Egypt) }\end{array}$ \\
\hline $\mathbf{8}$ & Congo Red & $\mathrm{C}_{32} \mathrm{H}_{22} \mathrm{~N}_{6} \mathrm{Na}_{2} \mathrm{O}_{6} \mathrm{~S}_{2}$ & $\begin{array}{c}\geq 97.0 \% \\
\text { Analytical } \\
\text { Standard }\end{array}$ & $\begin{array}{c}\text { Sigma-Aldrich } \\
\text { (USA) }\end{array}$ \\
\hline $\mathbf{9}$ & Ethanol & $\mathrm{C}_{2} \mathrm{H}_{5} \mathrm{OH}$ & Absolute & $\begin{array}{c}\text { Sigma-Aldrich } \\
\text { (USA) }\end{array}$ \\
\hline \hline
\end{tabular}




\section{FIGURES}<smiles>Nc1c(N=Nc2ccc(-c3ccc(N=Nc4cc(S(=O)(=O)O[AlH2])c5ccccc5c4N)cc3)cc2)cc(S(=O)(=O)O[Na])c2ccccc12</smiles>

Figure (1): Congo red Structural Formula

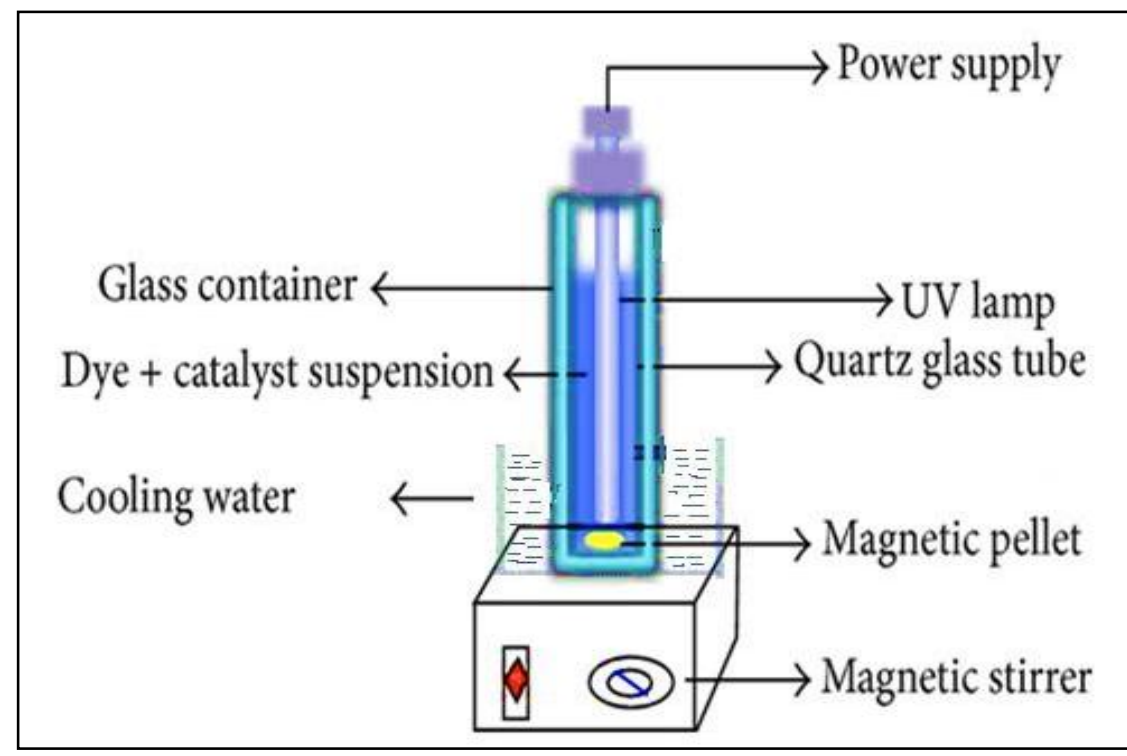

Figure (2): the photochemical cell used in the photo catalytic process

Vol.(50); Iss.(8); No.(5); Aug. 2021 
Journal of Environmental Sciences (JES)

Faculty of Graduate Studies and Environmental Research, Ain Shams University

Morsi. et al.

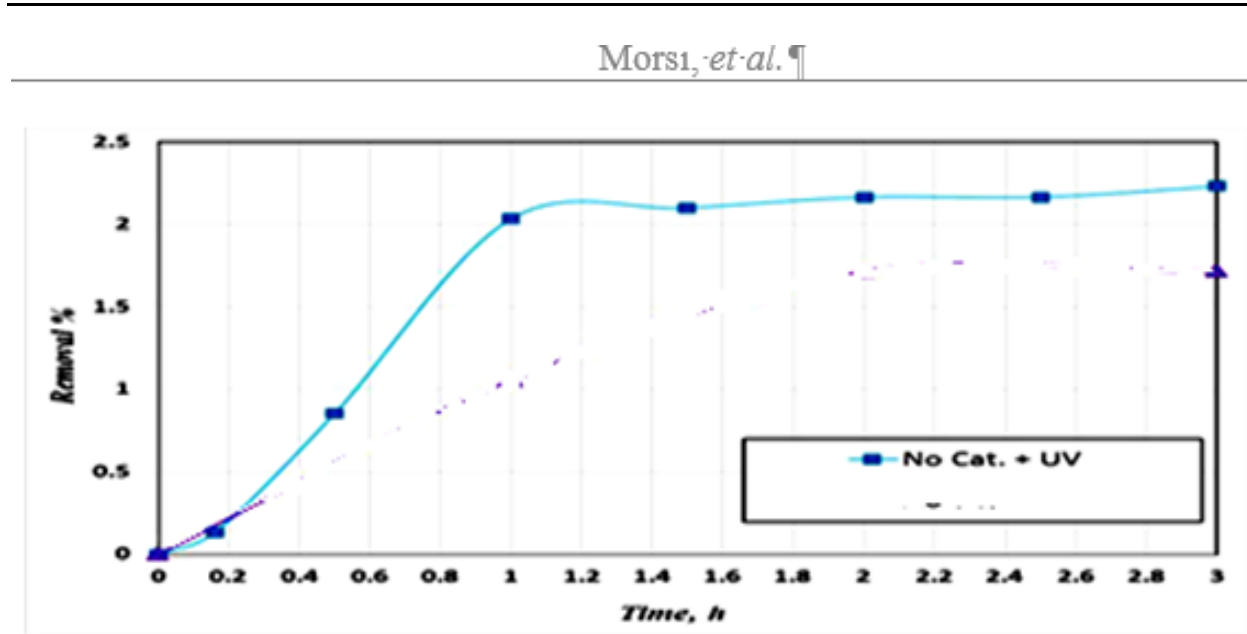

Figure (3) Stability of CR in aqueous solution with UV at pH6 and ambient temperature $25^{\circ} \mathrm{C}$

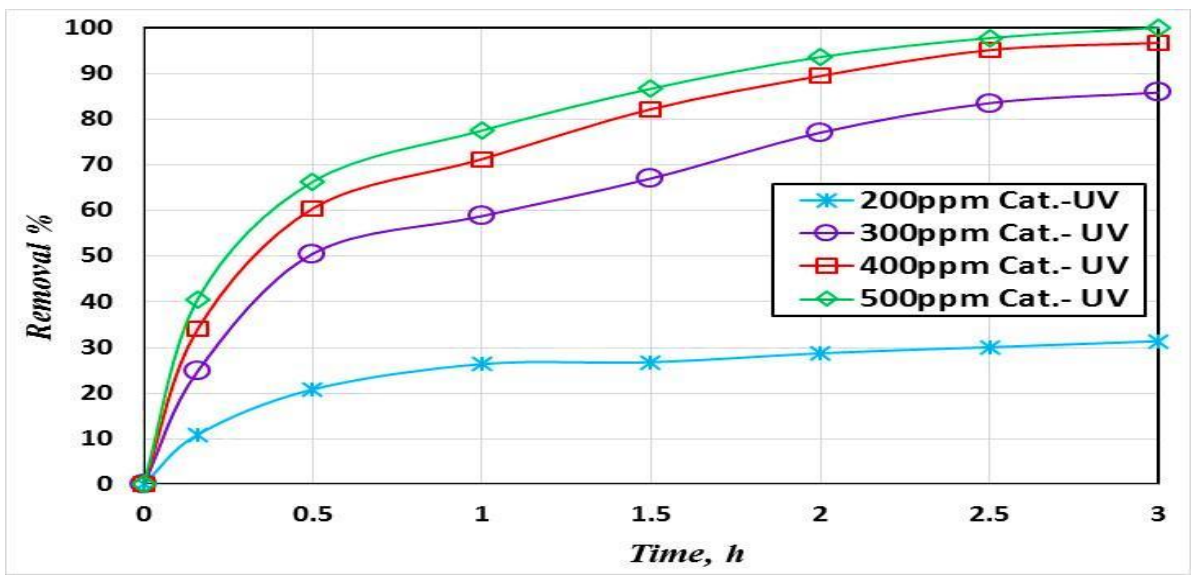

Figure (4): The Effect of mass concentrations of $\mathrm{Ni}_{0.5} \mathrm{Zn}_{0.5} \mathrm{Fe}_{2} \mathrm{O}_{4}$ nanoparticles on photocatalytic removal profile of $\mathrm{CR}(40 \mathrm{ppm})$ in duration time of $3 \mathrm{~h}$ at pH6 and ambient temperature $25^{\circ} \mathrm{C}$. 


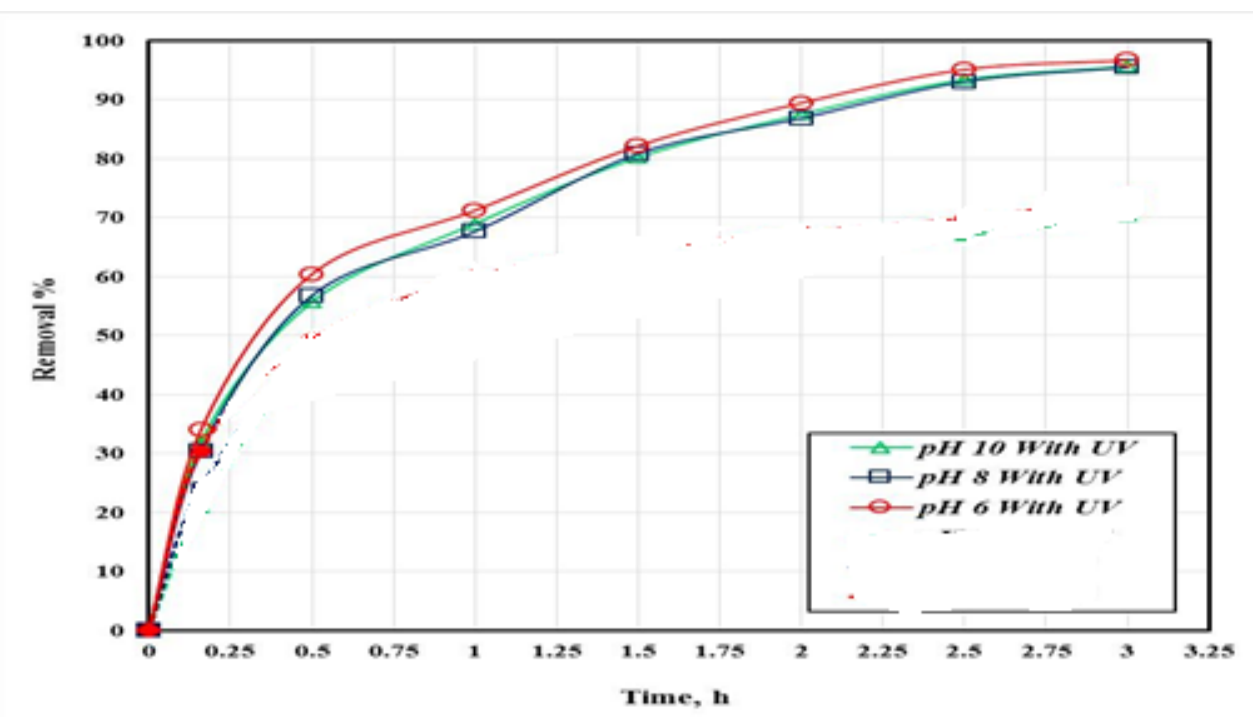

Figure (5): Effect of $\mathrm{pH}$ on removal profile of $40 \mathrm{ppm}$ Congo red by $400 \mathrm{ppm}$ $\mathrm{Ni}_{0.5} \mathrm{Zn}_{0.5} \mathrm{Fe}_{2} \mathrm{O}_{4}$ nanoparticles at ambient temperature $25^{\circ} \mathrm{C}$

\section{REFERENCES}

Aoa Y., Xua J.,Fua D., Shen X.,Yuan C “A simple route for the preparation of anatase titania-coated magnetic porous carbons with enhancedphotocatalytic activity" CARBON 46 ( 20008 ) 596 603

Aoa Y., Xua J.,Fua D., Shen X.,Yuan C. “A novel magnetically separable composite photocatalyst: Titania-coated magnetic activated carbon" Separation and Purification Technology 61 (2008) 436441

Aoe Y, ${ }^{\text {b,c }}$, Xua J ${ }^{\text {b,c }}$, shenb X, Yuanb C."Magnetically separable composite photocatalyst with enhanced photocatalytic activity" Journal of Hazardous Materials 160 (2008) 295-300

Vol.(50); Iss.(8); No.(5); Aug. 2021 
Brar $\mathrm{S}^{\mathrm{a}}$, Verma $\mathrm{M}^{\mathrm{b}}$, Tyagi R.D ${ }^{\mathrm{a}}$, Surampalli R.Y $\mathrm{Y}^{\mathrm{c}}$ "Engineered nanoparticles in wastewater and wastewater sludge - Evidence and impacts" Waste Management 30 (2010) 504-520

Chenga $\mathrm{Y}^{\mathrm{b}, *}$, Jiaoa $\mathrm{C}^{\mathrm{b}}$, Fana W. "Synthesis and characterization of coated zero-valent iron nanoparticles and their application for the removal of aqueous $\mathrm{Pb}^{2+}$ ions" Desalination and Water Treatment 54 (2015) 502-510

Di Paolaa A $\mathrm{A}^{\mathrm{b}}$,Lopeza E. ${ }^{\mathrm{b}}$, Marcia G. ${ }^{\mathrm{b}}$, Palmisano $\mathrm{L}^{\mathrm{a}, \mathrm{b}}$, "A survey of photocatalytic materials for environmental remediation" Journal of Hazardous Materials 211-212 (2012) 3-2

Jumeria F.A., Lima H.N., Ariffina S.N., Huangc N.M., Fatinc P.S.Chaid C.H, HarrisoneI

"Microwave synthesisofmagneticallyseparable $\mathrm{ZnFe}_{2} \mathrm{O}_{4}$-reduced graphene oxide for wastewater treatment" Ceramics International40(2014)7057-7065

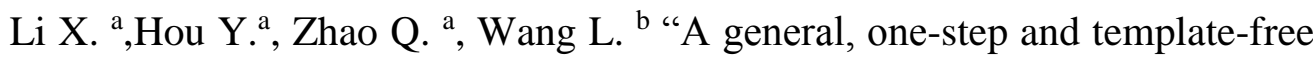
synthesis of sphere-like zinc ferrite nanostructures with enhanced photocatalytic activity for dye degradation" Journal of Colloid and Interface Science 358 (2011) 102-108

Mahmoud H., El-Molla S., Saif M. "Improvement of physicochemical properties of $\mathrm{Fe}_{2} \mathrm{O}_{3} / \mathrm{MgO}$ nanomaterials by hydrothermal treatment for dye removal from industrial wastewater" Powder Technology 249 (2013) 225-233

Peternela $\mathrm{W}^{1}$, Fuentes V. "Experimental Investigation of the Co precipitation Method: An Approach to Obtain Magnetite and Maghemite Nanoparticles with Improved Properties" Journal of Nanomaterials Volume 2014, Article ID 682985, 10 pages

Prayeena K. ${ }^{1,2^{*}}$,Sadhana K. ${ }^{3}$ " Ferromagnetic Properties of $\mathrm{Zn}$ substituted Spinel Ferrites for High Frequency Applications"International Journal of Scientific and Research Publications, Volume 5, Issue 4, April 2015 
Rahimi R., Kerdari H., Rabbani M., Shafiee Majid "Synthesis, characterization and adsorbing properties of hollow $\mathrm{Zn}-\mathrm{Fe}_{2} \mathrm{O}_{4}$ nanospheres on removal of Congo red from aqueous solution" Desalination 280 (2011) 412-418

Sua M., Head C, Sharmab V., Asia M., Xiaa D., Xiaa, X. zhong, L. Denga, Y. Xionga "Mesoporous zinc ferrite: Synthesis, characterization, and photocatalytic activity with $\mathrm{H} 2 \mathrm{O} 2 /$ visible light" Journal of Hazardous Materials 211-212 (2012) 95- 103

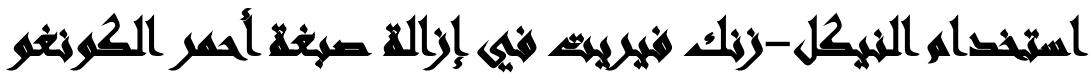

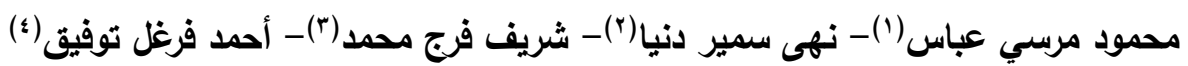

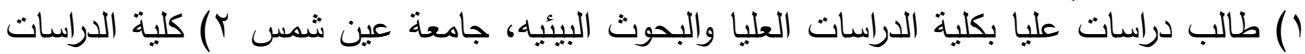

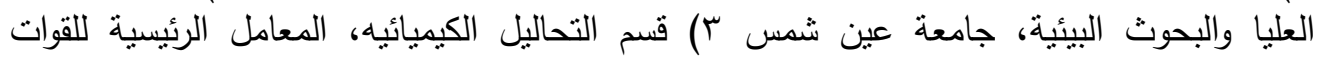
المسلح \&) قسم الهندسة النوويه، الكليه الفنيه العسكريه

\section{(المستخلم}

تستخدم صبغه احمر الكونغو العضويه كنموذج للملوثات العضويه للمياه، وفي هذه الورقها

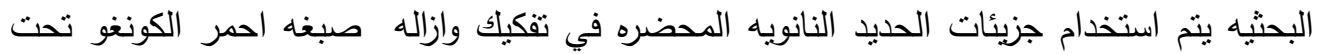

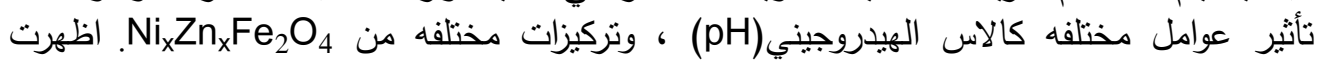
النتائج نجاح طريقه التحلل الضوئي التحفيزي في ازاله

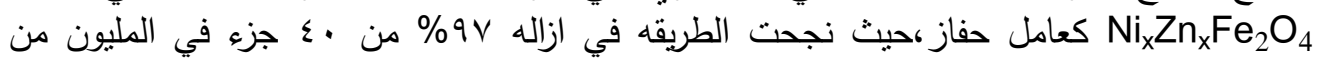

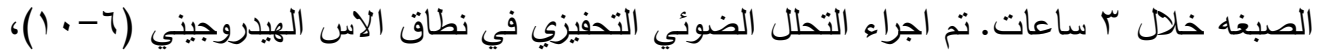

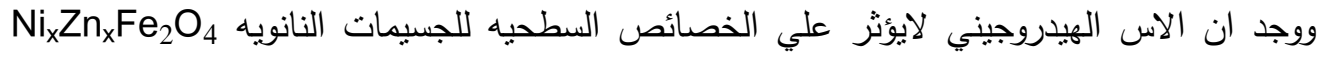

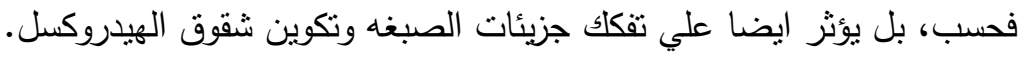

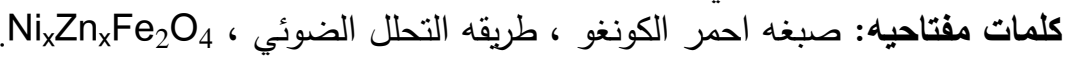

